\title{
Origens, Evolução e Tendências da Indústria de Máquinas Agrícolas ${ }^{1}$
}

\author{
Carlos Eduardo de Freitas Vian², Adilson Martins Andrade Júnior ${ }^{3}$, \\ Luis Gustavo Baricelo ${ }^{4}$ e Rodrigo Peixoto da Silva ${ }^{5}$
}

Resumo: $\mathrm{O}$ presente trabalho contribui com o estudo da gênese e da evolução histórica da indústria de máquinas e implementos agrícolas, destacando o papel de algumas empresas e como suas estratégias moldaram a estrutura produtiva e de mercado atuais, um "oligopólio diferenciado-concentrado mundial". Do ponto de vista metodológico, este é um texto qualitativo-quantitativo, exploratório e descritivo. A pesquisa bibliográfica mostrou que existiam poucos trabalhos sobre a evolução da estrutura de mercado e das empresas atuantes neste segmento, o que gerou a necessidade de um levantamento exploratório de dados e uma ampla revisão de literatura. $\mathrm{O}$ texto mostra a importância do progresso técnico e dos ganhos de escala no processo competitivo deste setor. $\mathrm{O}$ trabalho conclui que o setor tem as características de um oligopólio diferenciado-concentrado, sendo a inovação e a diferenciação de produtos através da fidelização dos clientes à marca de dois importantes instrumentos competitivos, assim como as economias de escala e escopo. Outra característica fundamental é o caráter global desta concorrência, com poucas empresas com atuação mundial e muitas com atuação regional ou local.

Palavras-chaves: Máquinas agrícolas, história setorial, competitividade, inovação, estratégias competitivas.

\footnotetext{
Abstract: This paper aims to resume the agricultural machinery history and development, as well as their majors companies, in order to understand the current market structure and the prospects for their future. The first discussion is related to the importance of technical progress to compete in this environment. We study the competition and technical progress in this industry, focusing on technological trajectories and on collecting information from the literature about the development of this industry. The study concludes that

1 Os autores agradecem o esforço do Prof. Ricardo Reis, membro do Comitê Editorial da RESR, que cuidou pessoalmente da avaliação deste texto, permitindo que o editor da revista e autor deste artigo, Carlos Vian, submetesse o manuscrito à RESR sem ferir o sistema de "blind review".

2 Professor Doutor da ESALQ/USP. E-mail: cefvian@usp.br

3 Graduado em Economia pela ESALQ/USP. E-mail: admartins@deloitte.com

4 Mestrando ESALQ/USP. E-mail: lgbaricelo@hotmail.com

5 Mestrando ESALQ/USP. E-mail: rodrigo.peixoto@hotmail.com
} 
the industry retains some differentiated oligopoly characteristics, with innovation and product differentiation as important competitive tools. Another key aspect is the global nature of this competition.

Key-words: Agricultural machines, industry history, competitiveness, innovation, strategies.

Classificação JEL: L1, L16, L64, N6.

\section{Introdução}

Este artigo é de grande importância para a literatura sobre economia agroindustrial, pois trata de um segmento produtivo extremamente relevante para a produção agrícola, mas que tem sido pouco estudado no Brasil e no mundo. Não se pode precisar porque isto ocorreu, mas constatou-se a falta de pesquisas científicas contínuas e que tratassem de aspectos como estrutura de produção, inovação, concorrência e competitividade, entre outros aspectos relevantes para o entendimento da dinâmica do setor.

O surgimento das máquinas e implementos para a agricultura no século XIX possibilitou ganhos de produtividade agrícola e do trabalho, mudando definitivamente a trajetória das técnicas de produção e elevando a oferta de produtos agrícolas no mundo. Por outro lado, este processo reduziu a necessidade de envolvimento de mão de obra na produção agrícola.

Desde esta época, a evolução técnica do setor foi constante e gerou crescente oferta de equipamentos que utilizam tecnologias cada vez mais avançadas, contribuindo para o aumento da produtividade no campo. Por outro lado, a indústria se concentrou e passou a investir altas quantias em inovação tecnológica. Estes são elementos importantes que foram estudados para possibilitar a análise das tendências históricas do setor.
Como citado acima, devido à relevância atual do setor na economia mundial, é difícil entender a escassez de trabalhos científicos nesta área. Os autores dedicaram-se à ampla pesquisa em periódicos científicos e em bibliotecas especializadas, todavia, encontraram poucas obras de referência, mas que possibilitaram sistematizar a descrição do histórico do setor de máquinas e implementos agrícolas, detalhar a sua evolução tecnológica, entender a atual estrutura do mercado e apontar perspectivas futuras.

O texto ressalta a importância do progresso técnico contínuo e das inovações radicais e incrementais como instrumentos para competir neste segmento produtivo. Com base na revisão de literatura e na pesquisa de campo, foi possível entender as trajetórias tecnológicas adotadas pelas principais empresas que atuam no setor e as modificações na estrutura de mercado que são, ao mesmo tempo, condicionantes e resultantes destas trajetórias. Atualmente, o setor pode ser descrito como um oligopólio diferenciado-concentrado, no qual a inovação, diferenciação de produto e economias de escala são instrumentos importantes de concorrência.

Inicialmente, buscou-se entender, por meio da revisão de literatura e dos dados coletados, a evolução das técnicas de produção e da estrutura da indústria até 1990. Os textos básicos para esta análise foram Fonseca (1990) e Kudrle (1975), 
que fizeram um levantamento completo da história e formação do setor em âmbito mundial e no Brasil. Para complementar, as informações foram consultadas em bibliografias sobre a história do desenvolvimento da agricultura americana, um dos berços do setor, evolução das máquinas e sobre a história das empresas líderes.

Esta pesquisa caracteriza-se, quanto à natureza, como pesquisa aplicada, que tem por objetivo conceber conhecimentos para aplicação na prática, direcionados à solução de problemas específicos. Com relação à abordagem, ressalta-se que este trabalho tem caráter qualitativo-quantitativo. A abordagem qualitativa "[...] tem por objetivo a coleta de elementos não disponíveis que, ordenados sistematicamente, de acordo com processos adequados, possibilitam o conhecimento de uma determinada situação ou hipótese" (MUNHOZ, 1989, p. 85). Em contrapartida, a abordagem quantitativa busca medir o grau em que algo está presente. Esta metodologia requer o uso de técnicas de descrição e tabulação de dados. O emprego conjunto da pesquisa qualitativa e quantitativa oportuniza a extração de mais informações do que se poderia obter de maneira isolada (FONSECA, 2002; SCHMIDT, 2006).

No que tange ao objetivo, este trabalho pode ser considerado como de natureza exploratória, pelo fato de esta pesquisa ser realizada sobre um problema ou questão que tem grandes lacunas na literatura, sendo pouco explorado, bem como de natureza descritiva, pelo fato de se procurar descrever/analisar a evolução histórica do setor de máquinas e implementos agrícolas no mundo.

Quanto aos procedimentos metodológicos adotados, este trabalho teve origem numa pesquisa bibliográfica (dados secundários) que consistiu primeiramente em apresentar os dados da evolução do setor de máquinas agrícolas e seus principais determinantes.

A relevância deste texto está na sistematização da literatura existente, descrição de fontes de dados, no uso de uma metodologia exploratória para obtenção de dados e na proposta de uma agenda de pesquisa sobre o setor.
O trabalho está organizado em nove seções, além desta introdução. A segunda seção apresenta o referencial teórico e conceitual que serviu de base para a pesquisa, classificando e contextualizando o setor de máquinas agrícolas. A terceira seção se refere às condições que possibilitaram a gênese da indústria de máquinas e implementos agrícolas e às mudanças que esta proporcionou para a agricultura. A quarta seção descreve a evolução tecnológica das máquinas agrícolas durante o século XX, com ênfase no mercado de máquinas agrícolas no período pós-Segunda Guerra Mundial. A quinta seção discute a importância da economia de escala para este setor; a sexta seção trata das estratégias (full-line e long-line) adotadas pelas empresas; a sétima seção descreve o panorama atual das empresas do setor, bem como os investimentos que elas vêm realizando. A oitava sistematiza a evolução histórica e técnica. A nona seção traz as conclusões e uma agenda que propõe novos temas a partir das contribuições do texto.

\section{Aparato teórico e conceitual de referência}

Este estudo se insere na literatura sobre "Economia Industrial" e "História de Empresas e Setorial", que se propõem a entender a dinâmica setorial a partir da estrutura de mercado, forma de concorrência e estratégias competitivas adotadas pelas empresas e suas mudanças no tempo. Nestas correntes teóricas e de pesquisa, existem várias tipologias de mercado que são determinadas pela relação entre o número de empresas, escala de produção e estratégias adotadas pelos agentes, dentre elas a inovação tecnológica (VIAN, 2003; VIAN, 2009; CHANDLER).

A teoria microeconômica divide os mercados em concorrenciais (concorrência perfeita) e não concorrenciais (monopólio, concorrência monopolística e oligopólios). A Figura 1, a seguir, mostra como o grau de concorrência varia entre essas estruturas de mercado, aumentando à medida que se aproxima da concorrência perfeita e diminuindo no sentido contrário. 
Figura 1. Principais estruturas de mercado: grau de concorrência

Grau de concorrência diminui

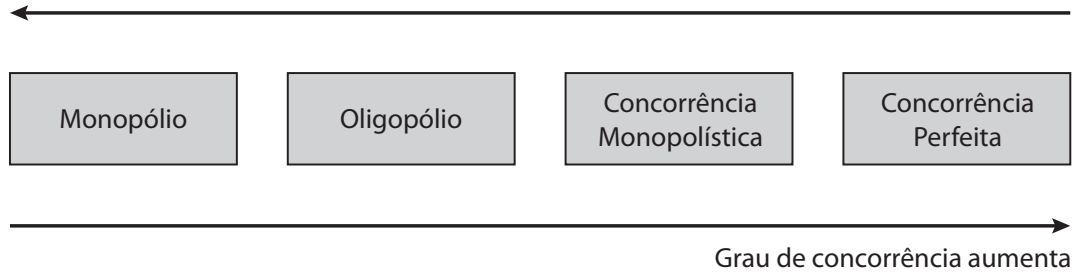

Fonte: Elaboração dos autores.

Por sua vez, a corrente de História Econômica de Empresas traz evidências de que há uma evolução na maioria dos setores no sentido de diminuir a concorrência e o número de ofertantes, ou seja, os setores têm uma tendência à concentração e ao aumento da escala de produção. Como exemplo, pode-se citar o segmento produtivo de máquinas agrícolas, objeto deste estudo, que em sua gênese era um mercado competitivo e evoluiu para um mercado oligopolizado no âmbito mundial.

As estruturas de mercado predominantes atualmente nas economias capitalistas são os oligopólios, os quais são formados por um pequeno número de grandes empresas que detêm grandes fatias de mercado, sendo possível a existência de um número variável de empresas médias e pequenas em alguns casos. Deste modo, os efeitos das decisões das empresas (quanto a preços, níveis de produção, diferenciação de produtos, lançamento de novos produtos e adoção de progresso técnico) não podem ser desprezados pelos concorrentes individuais, sejam eles grandes ou pequenos (VIAN, 2003).

Os oligopólios podem ser classificados, com base na estrutura técnico-produtiva (tamanho e número de empresas no mercado, tecnologia utilizada e características dos produtos) e no tipo de processo competitivo de cada mercado (preços, diferenciação de produto, lançamento de novos modelos, escala produtiva, custos etc.). Com base nestas características, as estruturas de mercado capitalistas podem ser classificadas da seguinte forma: oligopólio concentrado, oligopólio dife- renciado, oligopólio diferenciado - concentrado (ou misto), oligopólio competitivo e mercados competitivos (LABINI, 1984; TAVARES, 1986; GUIMARÃES, 1987; POSSAS, 1987; VIAN, 2008).

Assim, parte-se do pressuposto de que os mercados não são iguais, têm estruturas e dinâmicas diferentes que se manifestam por meio do número de empresas, tipo de produto fabricado (homogêneo ou diferenciado), tecnologia utilizada no produto e no processo de produção e abrangência geográfica da atuação dos fabricantes (local, regional ou internacional). Em alguns segmentos, o progresso técnico contínuo e inovações radicais esporádicas são fatores competitivos importantes para a evolução das empresas.

As economias de escala e de escopo presentes na indústria de máquinas agrícolas caracterizam as descontinuidades tecnológicas que definem um oligopólio concentrado. Estes fatores atuam como barreiras que operam "para fora", inviabilizando a entrada de novos concorrentes, na medida em que exigem grandes investimentos e conhecimento prévio dos métodos de produção para se alcançar um nível mínimo de competitividade.

A junção das descontinuidades tecnológicas e daquelas relacionadas às preferências dos consumidores caracteriza, portanto, o caso misto: o oligopólio concentrado e diferenciado. Este parece ser o caso da indústria de máquinas agrícolas, dados os grandes investimentos necessários para a criação de nova capacidade produtiva (custo fixo elevado) e a busca por uma relação mais próxima entre produtor e cliente, atribuindo grande 
importância às preferências do consumidor para garantir maior fidelização à determinada marca ou produto.

A diferenciação de produtos reflete as barreiras de entrada geradas pelas preferências do consumidor e estão relacionadas ao valor que este atribui à determinada marca de produto, seja devido à maior durabilidade das máquinas, seja por melhores serviços de assistência técnica e redes de distribuição, e à inovação de produto. De acordo com Labini (1956), o oligopólio diferenciado é caracterizado pelas preferências e ignorância dos consumidores e pela incerteza dos produtores:

“o elemento principal é dado pela preferência de certos consumidores para com os produtos de determinadas empresas, produtos que são ou que parecem para eles diferentes dos de outras empresas" (Labini, 1956).

Neste caso, observa-se a existência de barreiras que operam tanto "para dentro do grupo de empresas", dinamizando a concorrência entre as firmas já estabelecidas, quanto "para fora", gerando uma série de características prévias que a empresa deve possuir para atuar no mercado. A título de ilustração, pode-se considerar as despesas com promoção de vendas, que podem representar gastos elevados por um longo período de tempo, até que seja conquistado um número razoável de clientes que justifiquem estas despesas. Este elevado nível de investimento com a implantação das vendas representa um obstáculo à entrada de novos concorrentes no mercado.

Sylos Labini (1956) distingue três tipos de inovações, que podem consistir: 1) na produção de um novo bem, 2) na variação das técnicas de produção dos já existentes e 3) na variação da qualidade dos produtos. Em todos os casos, surgem oportunidades de investimento motivadas pela diminuição dos preços dos fatores produtivos, ou seja, pela queda dos custos de produção, pela diminuição do custo do dinheiro ou por um aumento de demanda.
O primeiro tipo de inovação descrito acima possibilita o surgimento de novos setores econômicos, cujas características do mercado consumidor e da produção industrial do novo produto é que irão ditar o porte das empresas do novo ramo, ou seja, se o investimento inicial for elevado, o setor será composto por empresas grandes que, quase sempre, já operam em outros setores. Nos dias atuais este é o caso mais comum, pois as inovações exigem grandes laboratórios de pesquisa, altos investimentos iniciais e grande quantidade de técnicos e operários especializados. As grandes empresas oligopolistas utilizam seu poder sobre as inovações, distribuindo no tempo a realização das mesmas, de modo a reduzir as perdas geradas pela obsolescência dos equipamentos instalados (VIAN, 2003).

A Teoria da Dinâmica Econômica formulada por Kalecki (1965) define inovação como: novas tecnologias e novos produtos que exigem novos equipamentos, novas fontes de matérias-primas, novas fábricas, novos meios de transporte etc.

Steindl (1974) mostra que a introdução de uma inovação depende de uma série de passos sucessivos: pesquisa básica, pesquisa aplicada, desenvolvimento, primeira produção comercial e difusão. Durante o processo de desenvolvimento de uma inovação geram-se conhecimentos e pessoal capacitado para desenvolver novas pesquisas, levando a um processo contínuo de incremento tecnológico. $\mathrm{O}$ autor afirma que $\mathrm{o}$ progresso técnico estimula o investimento em virtude da expectativa de lucros adicionais para o empresário inovador que introduz um novo produto ou processo de produção.

Como será demonstrado no correr deste artigo, a inovação tecnológica, seja ela de caráter radical ou incremental, é de crucial importância para o setor de máquinas agrícolas. Frequentemente, a inovação em máquinas agrícolas parte de um projeto já pré-concebido, que é chamado de guide-post. Segundo Fonseca (1990), o guide-post é uma ideia inicial, um projeto, que guia as inovações subsequentes que dele derivam. Pode-se recorrer aqui ao conceito de paradigma tecnológico, criado por Dosi (1988) 
para embasar teoricamente a ideia de guide-post. Segundo este autor, um paradigma é um padrão de solução de problemas; dentro deste padrão de solução são realizadas as inovações para incrementar ou modificar radicalmente o produto. Caso o produto não possua mais nenhum problema a ser resolvido, ou qualquer invenção que possa modificá-lo, considera-se que o paradigma está esgotado. Um novo paradigma será criado se o produto passar por mudança tão radical que não mais se identifique com o seu similar anterior. Este conceito é importante para entender o processo de diferenciação de produtos na indústria de máquinas agrícolas.

\section{Gênese da indústria de máquinas e implementos agrícolas no século XIX}

Este item é dedicado à sistematização da evolução técnica e estrutural da indústria, mostrando o papel dos "homens práticos" para a evolução tecnológica inicial do setor, visto que as primeiras inovações eram feitas com base na tentativa e erro de alguns agricultores e de seus familiares. Deve-se destacar também que as primeiras ferramentas e utensílios foram usados em culturas anuais, como os grãos ${ }^{6}$.

Até o século XVIII, a agricultura utilizava instrumentos rudimentares, fabricados artesanalmente com ferro e/ou madeira. A revolução industrial, a crescente população urbana e a maior demanda por alimentos geraram a necessidade de aumento da produtividade agrícola (DERRY e WILLIANS, 1977 apud FONSECA, 1990). Por estes motivos, fazia-se necessário o desenvolvimento tecnológico para aumentar a produtividade e atender à demanda crescente ${ }^{7}$.

6 Culturas perenes (como cana-de-açúcar e café) demoraram décadas para serem mecanizadas e ainda são intensivas em mão de obra. No Brasil, o nível de mecanização destas culturas ainda é heterogêneo entre as regiões, embora existam avanços constantes no uso de máquinas para a colheita.

7 Foi a partir da introdução das semeadeiras que o processo de modernização tomou impulso, já que esta nova técnica de plantio de grãos economizava 54,5 litros de sementes/ha e elevava a produtividade da colheita em 10,5 hectolitros/ ha (FONSECA, 1990).
Os primeiros implementos usados para a colheita de grãos (segadeiras) foram inventados simultaneamente na Grã-Bretanha e Estados Unidos em meados de 1780, mas só foram efetivamente usados meio século depois. A segunda geração de segadeiras surgiu em 1833, quando o americano Obed Hussey criou uma mais prática que a do escocês Bell. O modelo consagrou-se após os aperfeiçoamentos feitos por Cyrus McCormick (FONSECA, 1990; HUGHES, 1972; TEDLOW, 2002). Entre 1830 e 1860, as ceifadeiras e segadeiras para feno e trigo foram as grandes inovações, gerando espaço para o desenvolvimento de outros equipamentos dedicados à colheita.

Entre 1850 e 1870, a Inglaterra e a Europa deixaram de ser o principal centro técnico da agricultura. Nesse período, Estados Unidos, Austrália, Argentina, entre outros, tornaram-se grandes supridores de produtos essenciais, como trigo, produtos lácteos, carne e produtos tropicais (salvaguardando o açúcar, produzido pelo Brasil e outros países). Os EUA assumiram o papel principal no desenvolvimento tecnológico na fabricação de equipamentos agrícolas. No período entre 1780 e 1900, a área cultivada naquele país era de 160 milhões de hectares, mais de 10 vezes a superfície cultivável da Inglaterra e do País de Gales (HUGHES, 1972; FONSECA, 1990), graças à abertura da fronteira oeste e o uso de implementos de tração animal, inventados e produzidos por pequenas empresas industriais.

Rasmussen (1983 apud FONSECA, 1990) aponta que esta liderança dos Estados Unidos se deve à uma longa trajetória de desenvolvimento e incentivos que datam do século anterior. Várias pessoas foram determinantes neste processo. George Washington contratou um técnico britânico, Artthur Young, defensor do progresso tecnológico na agricultura visando o desenvolvimento técnico e o ensino de mecânica; Thomas Jefferson buscou melhorias e inovações mecânicas, desenvolvendo projetos para semear, seed drill, e outra série de utensílios agrícolas. A máquina de descaroçar o algodão foi um dos principais avanços no período, projetada por Eli Whitney. Considerada um autentica inovação, já que este processo 
demandava grande contingente de mão de obra, foi um equipamento que gerou grande aumento na produtividade da cultura.

O solo de pradaria ${ }^{8}$ norte-americano foi outro fator determinante para o desenvolvimento de novos implementos, já que os arados de madeira e ferro não deslizavam adequadamente para abrir os sulcos necessários para o plantio. O ferreiro John Deere (Illinois - EUA) desenvolveu, em 1837, arados de ferro forjado liso, que se adaptavam bem à agricultura da pradaria.

O sucesso das ceifadeiras e enfardadeiras de tração animal encorajaram inovações para a cultura do milho que aravam, semeavam e cobriam em uma mesma operação, e um ancinho ${ }^{9}$ para feno e grãos. Assim, as inovações permitiam o aumento da produtividade da mão de obra relativamente escassa nos países da Europa e Estados Unidos por conta da Revolução Industrial em curso.

Para Rasmussen (1983 apud Fonseca, 1990), é a guerra civil norte-americana que fornece todo o ímpeto para uma grande mudança agrícola e para a conversão de tração humana e tração animal para força mecânica.

Os EUA foram os pioneiros no uso de tratores, grandes trilhadoras e "combines", as colhedeiras movidas a vapor, que executavam em um dia a colheita de 12 hectares de trigo e realizavam todas as operações necessárias até o ensacamento do grão. Em Dakota, por volta de 1880, fazia-se aração em grande escala, com dezenas de arados trabalhando simultaneamente e paralelamente. Esses arados eram montados sobre pequenos carros sobre duas rodas em que um homem direcionava quatro cavalos que geravam a tração para o cultivo de imensas áreas.

8 Pradaria é uma planície vasta e aberta onde não há árvores nem arbustos, com capim baixo em abundância. Estão localizadas em praticamente todos os continentes, com maior ocorrência na América do Norte.

9 O ancinho é um instrumento utilizado na agricultura e na jardinagem, constituído por um longo cabo de madeira preso a uma travessa dentada, geralmente de metal. É utilizado para coletar materiais, como folhas, grama solta, palha, feno e também em hortas, para preparar a terra para o plantio. É conhecido ainda por gadanho ou rastelo.
Após o "Homestead Act"10, em 1862, a ocupação de novas terras nas pradarias seguida pela ocupação do oeste e também a construção das grandes estradas de ferro possibilitaram a criação de uma agricultura moderna e mecanizada nos Estados Unidos. As máquinas a vapor eram utilizadas em várias atividades agrícolas, sendo exemplo de sua utilização: Oliver Dalrymple, fazendeiro de trigo no Minessota, assim como outros fazendeiros do Red River Valley, em Dakota do Norte, em 1880, que iniciaram o cultivo de trigo usando tratores a vapor (RASMUSSEN, 1983).

Vale observar que a mecanização não ficou limitada às grandes fazendas monocultoras, mas expandiu-se para outros agricultores. Essa tendência à mecanização firmou-se no começo do século XX. As vendas anuais de máquinas agrícolas dos Estados Unidos, incluindo as exportações, alcançaram 101 milhões de dólares, frente a 7 milhões de dólares ao ano, alcançados 50 anos antes (FONSECA, 1990).

Nesta fase, o crescimento do setor de máquinas agrícolas foi expressivo nos Estados Unidos e na Europa, sendo que as empresas aumentaram a escala de produção, passaram a utilizar novas formas de organização da produção e atingiram os mercados nacional e internacional. As empresas deixaram de ser unidades artesanais para serem manufaturas. No fim do século XIX, já se formavam oligopólios nos Estados Unidos e na Europa (CLARK, 1929).

Pode-se, então, afirmar que a produção artesanal dos implementos agrícolas realizada por vários homens inventivos assemelhava-se ao conceito de mercado concorrencial. A diferenciação de produtos não era grande, necessitava-se de pouca tecnologia e havia um considerável número de fabricantes destes implementos. Mas, à medida que surgia a demanda por implementos mais sofisticados, maior era a necessidade de capital investido.

\footnotetext{
10 Lei da Propriedade Rural (Homestead Act) foi uma lei criada pelo presidente Abraham Lincoln em 20 de maio de 1862. A lei determinava a transferência de terra do Estado para pequenos agricultores, incluindo os escravos negros, definitivamente libertados pela guerra.
} 
Alguns destes homens inventivos, como John Deere, passaram a organizar suas firmas de outra forma, as barreiras à entrada aumentaram e o número de empresas se reduziu. Deste modo, o mercado transitou com o passar dos anos para uma situação mais próxima ao oligopólio concentrado-diferenciado. A diferenciação de produtos, especialmente pela fidelização à determinada marca, os ganhos de escala e de escopo passam a ditar a dinâmica deste mercado, como foi apontado na primeira seção do artigo.

\section{Evolução tecnológica dos tratores no século XX}

A tração animal foi completamente substituída por tratores antes da Segunda Guerra Mundial na América do Norte e logo após na Europa, excluindo a Itália, onde o processo de substituição foi mais lento. O primeiro trator a gasolina foi fabricado em 1892 por Froelich, em Dakota do Sul, e seu projeto foi adquirido por John Deere, servindo de base para a fabricação de seus tratores no início do século XX. A primeira fábrica de tratores, a Hart-Parr Company, surgiu em Iowa (EUA) em 1905, por meio do esforço de um grupo de pesquisadores da universidade de Wisconsin, e logo depois, a empresa foi incorporada pela Oliver (FONSECA, 1990).

$\mathrm{O}$ mercado de tratores movidos a gasolina ou diesel cresceu lentamente até a Primeira Guerra Mundial, tendo como principais fatores relevantes para o seu desenvolvimento a elevação de preços dos produtos agrícolas, a escassez de mão de obra e o estímulo do governo norte-americano, encorajando a transição para a mecanização por parte dos fazendeiros.

Na década de 1920, a mecanização da agricultura nos Estados Unidos aumentou moderadamente, mas, após o New Deal ${ }^{11}$, o processo se acelerou devido aos programas agrícolas

11 O New Deal foi uma série de programas implementados nos Estados Unidos entre 1933 e 1937, no governo de Franklin Delano Rooselvelt, com o objetivo de recuperar e reformar a economia norte-americana e assistir aos prejudicados pela Grande Depressão. do Estado. Após a Segunda Guerra Mundial, com demanda mais elevada, o mercado interno norte-americano para máquinas e implementos aumentou consideravelmente.

No período entre as guerras mundiais, o desenvolvimento tecnológico foi muito significativo e se deu por meio de inovações de produto e avanços consideráveis no processo de produção, principalmente com a adoção da linha de produção e da divisão do trabalho.

Até 1913, o processo de montagem dos tratores era completamente descontínuo e quase artesanal. Neste ano, tentou-se implantar o primeiro processo de montagem de tratores em série. Nos anos seguintes, as melhorias nos projetos e peças (novas formas de ignição e motor a querosene) permitiram maior arranque e tração para os tratores. O desenvolvimento de um sistema eficiente de acionamento de força em 1918 aumentou a transmissão de força para diversos implementos agrícolas.

Por volta de 1920, já existia um projeto básico de trator, que permaneceu inalterado durante as duas décadas seguintes. O Fordson (ver Figura $2^{12}$ ) pode ser considerado como inovação primária, ou, nas palavras de Fonseca (1990), um "guide-post", um padrão tecnológico a ser seguido e melhorado, como observado acima. A partir do paradigma do Fordson foram incorporadas várias formas de inovação e melhorias técnicas.

O Fordson foi o primeiro trator a obter grande sucesso em comparação com os modelos concorrentes, devido à expressiva redução de custos com a produção em série na linha de montagem e com a padronização das peças. Em 1918, a Ford representava $25 \%$ do mercado de tratores dos Estados Unidos, que era estimado em 135 mil unidades e, em 1925, já possuía 70\% dos 158 mil tratores vendidos nos EUA (FONSECA, 1990). Ford aplicou à produção de tratores os mesmos princípios que nortearam a produção de carros: simplicidade do projeto, baixo custo e facilidade de manutenção.

12 Este trator foi lançado pela Ford em 1917. 
O Farmall, da International Harvester, foi o primeiro trator adaptado a uma série de operações agrícolas, com melhorias no sistema de tração de implementos. Entre 1920 e 1940, foram lançadas outras novidades. A John Deere introduziu o modelo " $\mathrm{D}$ ", com custo menor em relação ao Fordson, que serviu como referência para outros tratores de sua linha, até os anos 1960. Por sua vez, H. Hans, em 1921, desenvolveu o Lanz Bulldog, que tinha a vantagem de ser movido tanto a gasolina quanto a óleo vegetal e apresentava número reduzido de componentes.

Outro desenvolvimento que ocorreu no período foi a substituição da roda de ferro pela pneumática de borracha em 1938. A Continental iniciou a fabricação de pneus para Lanz em 1931. Com a introdução dos pneumáticos, o trator ganhou maior equilíbrio e estabilidade, facilitando a sua operação em campo. Outro ponto importante do uso de pneus de borracha nos tratores foi melhorar consideravelmente seu deslocamento ao longo de estradas pavimentadas ao mesmo tempo em que representava aumento de conforto para o tratorista. Entre 1935 e 1940, a comercialização destes tratores passou de $14 \%$ para 95\% (FONSECA, 1990).

O guide-post Farmall foi o padrão máximo de desenvolvimento tecnológico durante o período 1920-1940. Os desenvolvimentos tecnológicos que ocorreram a partir deste período foram aperfeiçoamentos do projeto básico inicial. Com o correr do tempo, o espaço para agregar novas modificações, supondo inalterável a concepção tecnológica do modelo Farmall, estava esgotado.
Com outras melhorias incrementais, mas significativas na indústria de tratores, a evolução do controle hidráulico de "três pontos" e do engate possibilitaram uma série de pequenos aperfeiçoamentos, permitindo também melhoria no desempenho do conjunto trator-implemento. Kudrle (1975) acredita que este desenvolvimento, que se deu por meio do trator Ferguson, representou um salto considerável, sendo uma "revolução" no processo de desenvolvimento de tratores. Este sistema hidráulico, patenteado pela Ferguson em 1926 na Inglaterra, foi adaptado a um trator nos Estados Unidos em 1939, por meio de um acordo de fabricação com a Ford, que durou até 1946. Em 1936, a Deere patenteou o seu próprio sistema hidráulico.

O sistema Ferguson passou a ser um novo guide-post. Trouxe um novo conceito, em que se valorizava o conjunto trator-implemento, chamado de sistema de montagem integral. Este modelo trouxe inovações importantes no mecanismo de engate e controle dos implementos, que permitia melhor distribuição do peso do trator em operação, facilitando a operação com os implementos associados. O desenvolvimento do sistema de "três pontos" e do controle hidráulico remoto na operação com implementos permitiram superar o problema da resistência do solo sobre os implementos e a tendência de o trator tombar. Para compensar, adicionava-se peso na frente do equipamento, o que representava outro problema. A introdução deste engate no mecanismo de junção do trator com os seus implementos proporcionou maior flexibilidade

Figura 2. Alguns modelos de tratores agrícolas

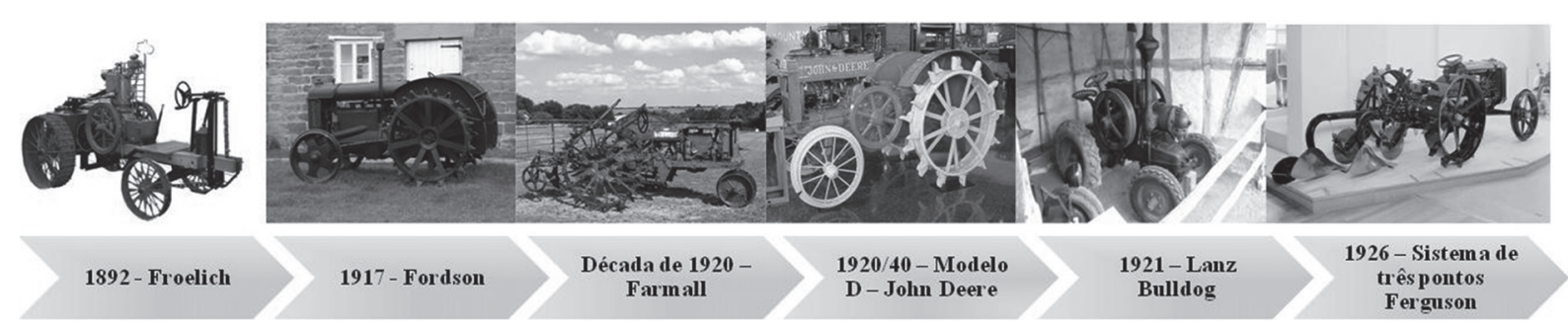

Fonte: Elaborado pelos autores. 
às operações, permitindo que se trabalhasse com implementos cada vez mais pesados.

Este trator passou a ser oferecido em escala industrial em 1946, tornando-se praticamente universal após os aperfeiçoamentos realizados pela outras fabricantes. Na década de 1950, o modelo tinha sido adotado pela Europa, Austrália, América do Sul e diversos outros países.

As ondas de desenvolvimentos tecnológicos na indústria de tratores no pós-guerra tiveram muitas sinergias com a indústria automobilística e de autopeças, pois muitas melhorias técnicas derivaram das efetuadas em automóveis e caminhões. Dentre as inovações incrementais compartilhadas entre essas indústrias destacam-se: motores a diesel, mecanismo de direção hidráulica, sistema de transmissão automática e aperfeiçoamentos nos mecanismos de embreagem. Algumas melhorias foram desenvolvidas pela própria indústria de tratores, destacando-se o aperfeiçoamento do mecanismo de tomada de força contínua, introdução da tração nas quatro rodas; incorporação de rodas duplas e adoção de cabines de proteção do operador (FONSECA, 1990).

Segundo Sahal (1981 apud Fonseca, 1990), entre 1948 e 1968, a potência média dos tratores passou de $27 \mathrm{HP}^{13}$ para $70 \mathrm{HP}$. Outra tendência foi o surgimento de tratores de menor porte (minitratores ou motocultivadores), em que as melhorias introduzidas ajudaram a aumentar a estabilidade do veículo. O investimento no desenvolvimento de máquinas com potência maior foi dinamizado pelo crescimento do mercado europeu no pós-guerra e, também, pelo aumento das unidades agrícolas, em que o uso de máquinas de maior porte era mais eficiente.

Ao longo desta seção demonstrou-se a importância que as inovações tecnológicas tiveram no processo de desenvolvimento das máquinas agrícolas, especialmente nos tratores. No início da concepção dos tratores, as inovações eram do tipo radical, sendo que, até chegar ao guide-post Fordson, várias etapas foram necessárias e gran-

13 HP, Horse Power, é uma unidade de potência necessária para elevar verticalmente de 1 pé/min. uma massa de 33.000 libras. des transformações sobre o projeto original se realizaram. A partir do Fordson, as inovações passam a ser do tipo incremental, visando à melhoria da estabilidade da máquina e da acoplagem desta com seus equipamentos. Isto não significa dizer que as inovações incrementais não foram importantes; ao contrário, muitas delas modificaram radicalmente a parcela de mercado das empresas inovadoras, como foi o caso do Ferguson que, ao lançar seu sistema inovador de acoplagem via três pontos, ganhou uma grande fatia do mercado antes suprida pela Ford e pelo Farmall.

\subsection{Tendências de padronização da indústria de máquinas agrícolas}

Nos anos 1950, as máquinas agrícolas entraram em um processo de convergência. Este processo iniciou-se após a criação do design do trator Ferguson, que serviu de padrão para outros fabricantes. Kudrle (1975) analisou a absorção da tecnologia inovadora da Ferguson, introduzida no mercado em 1946, pelos Estados Unidos, Inglaterra e resto da Europa. A incorporação daquele padrão tecnológico foi mais rápida na Inglaterra do que nos Estados Unidos, já que naquele país o apego aos antigos padrões tecnológicos era maior. Já para o resto da Europa a incorporação foi mais lenta por motivos de renda rural, bem como da pequena dimensão dos estabelecimentos agrícolas dos países (FONSECA, 1990, p. 76).

Com o lançamento do Ferguson, a participação da Ford no mercado cai acentuadamente. Em 1952, a Ford se adapta aos novos padrões tecnológicos, seguida pela David Brown e Nuffield. A Harvester mantém-se atrás tecnologicamente nos mercados americano e europeu, devido ao seu fraco desempenho naqueles mercados. Nos anos 1960, os componentes hidráulicos eram considerados "luxo desnecessário" para os fabricantes europeus. Apenas na França a Massey e Harvester aperfeiçoaram sua capacidade de competição por meio de um mecanismo de elevação que facilitava a mobilidade dos implementos, diferente do Ferguson, pois este não tinha controle de profundidade e mecanismo de engrena- 
gem que possibilitasse a realização de múltiplas tarefas simultaneamente sem afetar sua força.

Na década de 1960, as manufaturas americanas fabricavam tratores cada vez mais semelhantes, com sistema hidráulico e mecanismos de transmissão muito parecidos, às vezes fornecidos pelos mesmos fabricantes. Apenas a John Deere se manteve fiel ao seu design tecnológico anterior (FONSECA, 1990).

Neste período, começaram a surgir, nos Estados Unidos e Europa, comitês e associações encarregados de sugerir especificações formais para os produtos - estabelecimento de dimensões e posicionamento de peças e componentes, visando, principalmente, o sistema de engate. Essas normas, em geral, surgiam originalmente nos Estados Unidos e eram disseminadas para o resto do mundo. Para a adequação às normas, fazia-se necessária a universalização do sistema de engate. Porém, esta estratégia estava em desacordo com as estratégias das maiores montadoras de tratores, que queriam manter seu controle sobre a comercialização dos componentes e implementos, incompatibilizando os implementos de outros fabricantes. Como consequência, houve grande proliferação de prestadores de serviços e produtores especializados em implementos que, por sua vez, eram associados por vínculos de fornecimento aos fabricantes de tratores. A tendência de padronização dos tratores tem grande influência na estrutura do mercado de máquinas agrícolas, sendo que esta padronização permitiu que as matérias-primas fossem comercializadas de forma ágil e padronizada (FONSECA, 1990).

Em alguns países houve tendência contrária à padronização. Na Alemanha, por exemplo, as unidades agrícolas eram de pequeno porte e utilizavam tratores de baixa potência, de um ou dois cilindros. A Daimler-Benz, em 1948, desenvolveu um projeto, Unimog, que era próximo de um cruzamento entre um trator e uma caminhonete pick-up com tração nas quatro rodas. Na Itália existia outro trator de pequeno porte e com tração nas quatro rodas, para adaptar-se à agricultura de relevos fortemente irregulares (FONSECA, 1990).
A tendência de padronização não foi tão forte para as colheitadeiras, já que para este produto a especificidade de cada cultura determinava sua tecnologia, sendo necessário desenvolvimento de componentes e implementos específicos e não generalizados, diferentemente do que ocorria com os tratores.

Segundo Fonseca (1990), o processo de dinamismo de inovação tecnológica foi diminuindo com a padronização, pois este processo congela a evolução através de "marcos de referência" (guide-post). No entanto, "a necessidade de adaptação dos equipamentos às condições de uso continua sendo uma das fontes mais importantes de diferenciação qualitativa dos produtos" (FONSECA, 1990). Essa inércia foi compensada pela economia de aprendizado tecnológico que se manifestou entre as indústrias de equipamentos e o conjunto de indústria metal-mecânica. Dentro da indústria de máquinas agrícolas, as empresas produtoras destes equipamentos tenderam a se organizar nos mercados de implementos, deixando os consumidores presos às suas decisões.

\subsection{Organização do mercado de máquinas agrícolas no pós-guerra}

Segundo Fonseca (1990), esta indústria se organizou como oligopólio diferenciado fortemente influenciado pelo processo de "mudanças cumulativas não radicais" (p. 84). Mesmo que as inovações não sejam radicais, apresentam dinamismo próprio, baseado na experiência e no learning by using e geralmente acompanham os avanços da indústria de autopeças e do complexo metalmecânico como um todo. Estes desenvolvimentos se davam após certo tempo de uso dos equipamentos pelos produtores e a o envio das informações para as fábricas. As empresas direcionaram seu foco para a competição na vida útil e no desempenho dos equipamentos. Outro diferencial das vendas é o foco na distribuição dos produtos, um dos principais fatores que levam as montadoras à liderança neste mercado. Outro ponto destacado pela autora é que: 
“[...] modificações tecnológicas no nível do produto rebatem sobre o processo de produção, exigindo inversões na etapa de desenvolvimento de produtos, na 'racionalização' dos métodos produtivos, bem como a modernização do processo de fabricação. Nessas circunstâncias a capacidade de financiamento das empresas torna-se um elemento crucial, embora possa ser parcialmente substituída por políticas de crédito facilitado e subsídios concedidos pelo Governo, pelo menos durante algum tempo. Além disso, a capacidade financeira deve ser suficientemente grande para permitir montar e manter eficiente sistema de distribuição em cada um dos mercados em que as empresas atuam, o que também exige investimentos" (p. 84).

Após o término da Segunda Guerra, houve grande aumento nas vendas de máquinas agrícolas, com rearranjo no número de empresas atuantes no mercado e mudança de liderança. A escassez de produto no mercado fez com que um trator fosse vendido por até duas ou três vezes o seu preço. A demanda era tão grande que, segundo Kudrle (1970), mais de 20 pequenas empresas passaram a atuar na indústria norte-americana de tratores nesse período. Porém, estas empresas fecharam com a primeira retração do mercado, que ocorreu na década de 1950, devido às dificuldades na execução de projetos mais sofisticados, elevados custos de produção e de distribuição. Outro fator importante após a Segunda Guerra Mundial foi a incorporação de vários avanços tecnológicos nos tratores e colheitadeiras que, além disso, eram modelos maiores e mais potentes.

Depois do período de intenso crescimento do setor no pós-guerra houve uma desaceleração nos mercados dos Estados Unidos, Japão e Europa, que permaneceram com taxas de crescimento menores, porém constantes, concentrando-se na reposição de máquinas obsoletas ou sucateadas. Nestas circunstâncias, o tempo de vida dos maquinários agrícolas se torna fator fundamental para venda de novos produtos nestes países. A durabilidade dos maquinários agrícolas de grande porte era avaliada entre 10 e 15 anos, tornando a renovação lenta e "infrequente". Estes fatores fizeram com que a expansão das vendas não fosse favorável. A forte padronização destes produtos causou uma inércia tecnológica no setor, fazendo com que os players baseassem seus produtos em concepções básicas, paradigmas representados pelos projetos mais utilizados e pequenos aperfeiçoamentos ao longo do tempo.

Na década de 1980 houve grades mudanças entre as principais empresas. Esta fase pode ser considerada como um período no qual os principais players realizaram fusões e aquisições, objetivando conquistar maiores parcelas de mercado além de diversificar e complementar as linhas de produção. As vendas de equipamentos atingiram a marca de US\$ 22 bilhões; deste valor, US\$ 8 bilhões apenas nos Estados Unidos. As empresas líderes em termos de vendas eram, em 1980: John Deere, International Harvester, Massey Ferguson, Fiat, Ford, New Holland, Tenneco-Case, Kubota-Tekko, Allis Chalmers e a empresa alemã Klocker Hunbold Deutz. Juntas, totalizavam cerca de $70 \%$ das vendas no mundo. Em 1985, estes players mudaram no mercado, com a Ford absorvendo a New Holland e a Case incorporando a International Harvester. A participação da Case no mercado americano e canadense era em torno de $8 \%$ em 1980, passando para $26 \%$ em 1985 nos EUA e no Canadá e assumindo 14\% da participação no resto do mundo. $\mathrm{O}$ trabalho de Bjornson e Klipfer (2000) vai além e diz que esta aquisição da International Harvester pela Case permitiu a esta última empresa galgar o posto de segunda maior empresa de máquinas agrícolas em termos de market-share mundial em 1985.

A integração Ford-New Holland teve como estratégia a diversificação de mercados dos conglomerados Ford e Sperry New Rand, já que, com a aquisição, a empresa conseguiu completar sua linha de equipamentos (FONSECA, 1990).

A norte-americana John Deere sustentava a liderança em termos de valor de venda, com $20 \%$ de todo o mercado mundial, concentrando suas 
vendas no mercado norte-americano. A Massey poderia ser classificada líder mundial em termos de unidades vendidas. A New Holland tinha liderança na venda de colheitadeiras, disputando com a Massey-Ferguson e com a Claas, empresa alemã (FONSECA, 1990).

A Fiat e Deere tinham como forte estratégia suas forças nos mercados nacionais. A Ford, Harvester e Massey desenvolveram estratégia de expansão global. A Massey, por sua vez, tinha a maior internacionalização, já que havia instalado plantas em mais de 20 países, explorando mercados como Brasil, Argentina, Índia, África do Sul, entre outros. Esta estratégia da Massey tinha como foco o fortalecimento de sua concorrência com as grandes empresas do período, Deere e Harvester e, também, como resposta aos incentivos à instalação de indústrias promovida pelos governos destes países. Após aventurar-se nestes mercados menos maduros e enfrentar grande crise financeira no final da década de 1970, as expectativas de vendas da Massey não se concretizaram, fazendo com que a empresa mudasse sua estratégia, retirando-se de alguns países e preservando apenas seu acordo de fornecimento de tecnologias às antigas subsidiárias, garantindo sua participação no mercado mundial.

É importante descrever o surgimento de uma nova e grande empresa durante a década de 1980. Um conjunto de aquisições ocorridas entre 1985 e 1990 acabou formando a empresa AGCO. Por volta de 1985, a Alis Chalmers Corporation vendeu sua parte de negócios referente a máquinas agrícolas para o grupo alemão Klochner-Humboldt-Deutz (KHD). A grave crise da agricultura americana dos anos $80 \mathrm{fez}$ com que este grupo passasse por um período de dificuldades financeiras e, para solucionar tal problema, um novo gerente, Robert Ratliff, foi contratado. (BJORNSON e KLIPFER, 2000). A partir da queda do Muro de Berlim, em 1989, tal gestor vislumbrou a possibilidade de expandir as vendas da KHD para o leste europeu e África. Em 1990, com o sucesso de tal estratégia e a consequente recuperação da empresa, o gerente Robert Ratliff comprou, junto de mais quatro empresários, a parte da KHD refe- rente à empresa Deutz-Allis, fabricante de máquinas agrícolas. Com a venda da Deutz-Allis, este grupo liderado por Ratliff se tornou a AGCO, acrônimo de Alis-Gleaner Corporation. Desde então, a AGCO se firmou como uma das maiores produtoras de máquinas agrícolas do mundo (BJORNSON e KLIPFER, 2000).

O grupo AGCO adotou uma estratégia de crescimento através de fusões e aquisições, comprando tanto empresas regionais quanto grandes grupos empresariais do ramo de máquinas agrícolas. As principais aquisições do grupo AGCO em 1991 foram a Hesston, empresa de feno e forragem, e a empresa White, produtora de tratores de grande porte. Em 1993, a AGCO adquiriu a tradicional empresa Massey Ferguson North America e, no ano subsequente, finalizou a aquisição deste grupo comprando a Massey Ferguson Limited, parte da Massey Ferguson que ainda produzia e vendia máquinas agrícolas fora dos Estados Unidos (BJORNSON e KLIPFER, 2000). Tal artigo afirma que a receita de vendas da AGCO dobrou após a aquisição da Massey Ferguson, permitindo que a empresa expandisse sua área de atuação em termos geográficos, sendo que, antes da aquisição, a receita de vendas da AGCO era proveniente do mercado norte-americano e, após a aquisição, 57\% da receita de vendas já correspondia a atuações fora do mercado americano (BJORNSON e KLIPFER, 2000).

Em síntese, o mercado de máquinas agrícolas do pós-guerra, especialmente durante as décadas de 1980 e 1990, é marcado por grandes transformações na estrutura de mercado com operações de fusões e aquisições, as quais tornaram o mercado ainda mais concentrado, enquanto que a competição deixa de ser a nível nacional e passa a exigir das empresas, devido à globalização, estratégias globais de atuação. Assim, este ramo produtivo passa a ter caráter competitivo cada vez mais transnacional e a sua estrutura passa de um oligopólio diferenciado para o diferenciado concentrado, em que as economias de escala e a diferenciação de produto são importantes. Estes aspectos serão detalhados na próxima seção. 


\section{Importância da economia de escala para o setor}

Fonseca (1990) aponta a importância das economias de escala até os anos 1990; porém, ressalta que a mesma poderia ser responsável por alto grau de concentração industrial. Economias de escala podem ser atribuídas a três fatores:

"custo de ampliação dos equipamentos e instalações incluindo indivisibilidades técnicas, custos decrescentes de operação devido à utilização mais 'eficiente' da mão de obra, matérias-primas, insumos e energia e, finalmente, economias de grande reserva ou estoques" (p. 95).

Como as firmas do setor de máquinas agrícolas necessitam de grandes investimentos para a construção de plantas, aquisição de equipamentos específicos para a linha de produção, investimentos em P\&D, em centros e canais de distribuição e investimentos em propaganda com a finalidade de criar certa fidelidade do cliente à marca, a firma deve atuar em uma escala mínima de produção relativamente alta. A título de ilustração, a empresa AGCO, responsável pela marca Massey Ferguson e Valtra, entre outras, inaugurou em 2013 uma fábrica na Argentina com capacidade de produção de 3,5 mil tratores/ ano; a média anual de investimento deste setor, no Brasil, é de R\$ 195,5 milhões, segundo dados da Anfavea (2012). Geralmente, essas empresas empregam por volta de 1.500 funcionários. Esta economia de escala existente no setor, ao mesmo tempo em que possibilita os investimentos necessários para a inovação tecnológica e melhorias de qualidade dos produtos ofertados ao longo do tempo, implica também em um mercado bastante concentrado.

Kudrle (1975), ao estudar a indústria americana e inglesa na década de 1960, encontrou evidências de que a margem de lucro das firmas aumenta conforme aumenta a escala de produção e a potência dos tratores fabricados. Este aumento das margens de lucro pode se dar tanto por aumentos de preços, quando as firmas exercem seu poder de monopólio, quanto por redução de custos, quando as firmas exercem seu poder de monopsônio. No estudo de Kudrle, a queda sempre aparecia mais acentuadamente nas escalas de produção acima de 20 mil unidades/ano.

Economias de escala nas compras são representadas principalmente por descontos dos fornecedores às empresas de máquinas agrícolas devido às compras em grande quantidade, ou seja, quando as firmas compradoras atuam em um mercado concentrado na compra de insumos e conseguem exercer grande pressão no sentido de reduzir os preços dos insumos (poder de monopsônio). As indústrias de tratores e colheitadeiras dependem fortemente de compras de peças e sistemas oriundos de outras indústrias e setores. Fonseca (1990) analisou estudo realizado pela UNTC e apontou que um trator "standard" (padrão) produzido na década de 1980 era composto por 2.000 partes, sendo que cerca de 1.400 peças dos tratores eram "manufaturadas por fornecedores que mantêm alguma forma de integração com a indústria de tratores".

Outro estudo apontado por Schwartzman apud Fonseca (1990) demonstra que os gastos com atividades administrativas, incluindo $\mathrm{P} \& \mathrm{D}$ para as grandes empresas do período analisado, correspondiam a $18 \%$ do custo total do produto (3\% administração, $7 \%$ redes de revenda, $5 \%$ financiamento e estoques e 3\% P\&D). Existe grande diferença no investimento em $P \& D$ entre as empresas: a Deere aplicava em torno de $5 \%$ de suas vendas, em quanto a Massey, de $2 \%$ a $3 \%$.

Outro fator importante a ser analisado é que economias de escala, no geral, são acompanhadas por economias de complementaridade, que podem ser obtidas por meio de um aumento mais que proporcional na produção de componentes e peças. A existência de economias de complementaridade está associada à semelhança entre elementos no processo de produção. Alguns exemplos de economias de complementaridade para tratores são: componentes produzidos, sistemas mecânicos e elétricos e motores (KUDRLE, 1970). 
As economias de escala, mesmo representando barreiras à entrada no setor, não implicam necessariamente em um ambiente de pouca concorrência. Ao possibilitar tamanho suficiente para que as empresas realizem investimentos expressivos em inovação de produtos e processos, tais barreiras tornam possível o uso de tecnologia como arma de concorrência. Segundo (FONSECA, 1990):

\begin{abstract}
"Sempre que há uma ameaça de deslocamento competitivo, seja ela real ou potencial, as empresas tendem a afastar-se da acomodação manifestando uma atitude mais agressiva em relação aos concorrentes. Nessas ocasiões a tecnologia pode ser usada como arma de concorrência, acelerando o processo de lançamento de novos produtos ou imprimindo maior qualidade aos produtos diferenciados, por exemplo".
\end{abstract}

\section{Estratégias de especialização das empresas e diversificação dos produtos (full-lines e long-lines)}

A combinação entre vantagens de especialização, proporcionadas pela existência de economias de escala, com certo grau de diversificação em torno de linhas e capacitação tecnológica são armas concorrenciais para as empresas atuarem no mercado, já que as grandes empresas, principalmente, têm como estratégia a integração da indústria em torno de full-lines ou long-lines, que refletem uma coerência estratégica da empresa de acordo com o seu nível de verticalização e as características de seus ativos fixos.

Dosi, Winter e Teece (1989) apud Fonseca (1990) discorrem sobre as noções de "coerência" ou "especialização coerente", permitindo a inclusão de várias linhas de produtos que tenham em comum vários procedimentos técnico-produtivos, conforme as características de seus ativos fixos, proporcionando, assim, as chamadas economias de escala ou economias de escopo. Essa estratégia explora as práticas e rotinas comuns aos processos de montagem, de modo a permitir intercâmbio máximo de peças, motores, peças estampadas e demais componentes.

Fonseca (1990) dividiu os equipamentos utilizados na agricultura em quatro grupos: tratores, colheitadeiras, implementos e equipamentos associados ao trator (preparo do solo, tratos e plantio) e os implementos usados após a colheita, para a possível classificação das empresas conforme sua estratégia, ou full-line, ou long-line, ou fornecedores especializados.

Sendo assim, fabricantes que atuam sobre uma base técnica semelhante, embora produzam para mercados diferentes e produzam pelo menos um dos grupos de equipamentos agrícolas com seus respectivos implementos e acessórios, podem ser classificas pela estratégia long-line, como, por exemplo, empresas que têm foco principal na fabricação de tratores específicos para a construção civil, mas aproveitam a similaridade do processo produtivo e consequentes economias de escopo e escala incluindo em sua linha de produção tratores agrícolas.

Já a estratégia full-line é adotada quando existem fortes convergências quanto aos métodos de fabricação e uso de insumos. Este tipo de estratégia ocorre quando a empresa fabrica pelo menos dois dos quatro grupos de equipamentos mencionados pela autora, o que, na prática, inclui fabricante de tratores e colheitadeiras, com seus acessórios, além de diversos implementos. Exemplos de conglomerados que utilizaram essa estratégia são: Deere, Chalmer, Harvester/Case, Massey (estas são as maiores empresas da época), assim como outras empresas menores: Kubotta e Deutz-Fahar. As vendas conjuntas destas empresas atingiram 54\% do total da indústria em 1980.

Uma das principais vantagens da estratégia full-line é atenuação da sazonalidade da demanda por seus equipamentos. No Brasil, por exemplo, a demanda por tratores é maior nos meses que antecedem o início das atividades de preparo do solo, de abril até setembro; já a demanda por colheitadeiras ocorre de novembro a fevereiro. Ao adotar a estratégia full-line, o fabricante 
de máquinas agrícolas poderá intensificar o uso de seus fatores ora na produção de tratores, ora na produção de colheitadeiras, evitando, assim, capacidade ociosa indesejada. Outra vantagem em adotar essa estratégia é a operação com revendedores exclusivos, já que o revendedor deve ter a capacidade de fornecer toda linha integrada, comprometendo-se completamente com o sucesso ou fracasso daquela empresa. Além de uma ampla rede de distribuição e assistência técnica, criando um vínculo entre agricultores, revendedoras e fabricantes, a empresa passa a receber informações essenciais sobre o desempenho de seus produtos ao longo do tempo. Estas informações são transmitidas pelos próprios agricultores às concessionárias e redes de assistência técnica e fornecem à empresa um caminho mais preciso na busca por melhorias e inovações em seus produtos. Quando a empresa tem capacidade de sistematizar este conhecimento, learning by using, incorporando-o às atividades de desenvolvimento de projetos e produtos, incentivará seu potencial tecnológico proveniente do aprendizado pelo uso.

Fonseca ressalta que a força da full-line na América do Norte foi consequência da necessidade da indústria de estabelecer contato direto com os dealers para efeito do financiamento do produto, viabilizando a aquisição de equipamentos pelos agricultores americanos e contornando o problema de baixo nível de renda. Além disso, grande parte do custo de distribuição naqueles países decorria do fornecimento de crédito para os distribuidores, permitindo-os manter estoques em termos de atacado.

\section{Dinâmica recente da indústria}

Como explanado nos itens anteriores, até a década de 1990 a indústria de máquinas agrícolas teve inovações incrementais, mantendo-se o padrão e o design até então desenvolvido. Sartti, Sabbatini e Vian (2009) apontam que o padrão de desenvolvimento do setor no período pode ser definido como um "somatório" de avanços condicionados pelas operações e pelas "adaptações" a outras condições de solo e clima e capacidade de adaptação de implementos melhores e mais pesados. Apenas nos anos 1990 surgiram algumas novas tendências em termos de design dos tratores.

Para estes autores, as tendências atuais de mercado são: maior potência e a automação das máquinas, permitindo maior eficiência e redução de custos, com uma estrutura de mercado mais concentrada do que nas décadas anteriores, buscando cada vez mais a diferenciação pela qualidade e por potência dos tratores e colheitadeiras.

A localização e a estrutura atual das indústrias de máquinas e implementos agrícolas foram condicionadas por um longo processo de evolução técnica e pela ocupação dos mercados domésticos dos respectivos países; porém, isso vem mudando, e atualmente estas indústrias estão se instalando em regiões com grande potencial para o setor, como o Brasil, Índia e China, com perspectivas para abastecerem também os países vizinhos e a África.

A Associação Alemã da Indústria de Máquinas Agrícolas (VDMA) estimou que a produção mundial de máquinas e implementos agrícolas variou de 48 bilhões de euros em 2005 para 57,1 bilhões em 2007. Vale destacar a maior participação da Índia e China e o crescimento da Europa e Estados Unidos, o que é consistente com a maior demanda por máquinas para atender a maior área cultivada e com modernização das frotas.

A maior parte da produção de máquinas agrícolas é proveniente da Europa Ocidental; a distribuição da produção, em 2005, se dá da seguinte forma entre as principais regiões produtoras de máquinas agrícolas: Europa Ocidental, com 43\%, América do Norte, com $28 \%$, Ásia e Pacífico, com $14 \%$ e América Latina, com $8 \%$. Além disso, algumas regiões se destacam como grandes exportadoras destes produtos, como a Europa Ocidental e a América do Norte.

Na Tabela 1 é demonstrada a evolução da demanda de máquinas e equipamentos entre 2001 e 2007. É notável a grande evolução da demanda asiática, que pode ser explicada pelo avanço da modernização da agricultura da China, Índia, Camboja, Vietnã, entre outros. 
Observa-se, também, que ocorreu um pico de demanda por máquinas na América do Norte em 2005, com queda no período seguinte. Os autores indicam que a variação poderia ser creditada às políticas de produção de bicombustíveis que incentivaram o aumento da produção de milho e ao processo de renovação da frota agrícola dos Estados Unidos, Canadá e México para atender a demanda das usinas de etanol.

A demanda mundial de máquinas em 2007, segundo a consultoria Freedonia, foi de US\$ 93,2 bilhões. A Europa Ocidental respondeu por $27 \%$ deste total; Ásia e Pacífico, por 37\%, América do Norte, $22 \%$ e demais regiões, $14 \%$. Esta consultoria estimou que a demanda mundial seria em torno de 112 bilhões de dólares em 2012. Este crescimento da ordem de $3,2 \%$ ao ano será puxado pelo crescimento da mecanização em países emergentes como China e Índia, devido aos seus baixos índices de mecanização, conforme demonstrado acima. Outra parcela será fruto da renovação da frota de países como Brasil, Argentina, Indonésia e Rússia, que ainda têm baixo índice de mecanização se comparados com os países da Europa e Estados Unidos (SARTTI, SABBATINI e VIAN, 2009).

A Tabela 2 mostra a evolução das exportações e importações de implementos agrícolas, tratores, colheitadeiras e cultivadores motorizados entre 2000 e 2007, segundo dados da Comtrade. Pode-se perceber que o comércio mundial cresceu a taxas significativas neste período, em média $36 \%$ ao ano. A maior parte deste comércio está concentrada no segmento de implementos agrícolas e peças, seguido de tratores e colheitadeiras e, por fim, dos cultivadores motorizados.

Grande parte destas transações se dá entre os países da Europa Ocidental e Estados Unidos,

Tabela 1. Demanda mundial de máquinas agrícolas por região - Anos selecionados

\begin{tabular}{llll}
\hline \multicolumn{1}{c}{ Região/ano } & $\mathbf{2 0 0 1}$ & $\mathbf{2 0 0 5}$ & $\mathbf{2 0 0 7}$ \\
\hline Ásia/pacífico & $31 \%$ & $34 \%$ & $37 \%$ \\
Europa Ocidental & $31 \%$ & $24 \%$ & $27 \%$ \\
América do Norte & $26 \%$ & $30 \%$ & $22 \%$ \\
Demais Regiões & $12 \%$ & $12 \%$ & $14 \%$ \\
\hline
\end{tabular}

Fonte: Sartti, Sabbatini e Vian (2009).

Tabela 2. Resumo das exportações e importações de máquinas e implementos agrícolas

\begin{tabular}{|c|c|c|c|c|c|c|c|c|c|c|c|c|c|c|c|c|}
\hline \multirow{2}{*}{ Ano } & \multicolumn{4}{|c|}{721 - Máquinas agrícolas* e peças } & \multicolumn{4}{|c|}{7211 - Cultivadores motorizados } & \multicolumn{4}{|c|}{7212 - Colheitadeiras } & \multicolumn{4}{|c|}{722 - Tratores } \\
\hline & $M$ & $X$ & $M(\%)$ & $X(\%)$ & $M$ & $X$ & $M(\%)$ & $X(\%)$ & M & $X$ & $M(\%)$ & $X(\%)$ & M & $X$ & $M(\%)$ & $X(\%)$ \\
\hline 2000 & 10,58 & 10,65 & 0,47 & 0,46 & 1,78 & 1,88 & 0,41 & 0,41 & 6,15 & 6,15 & 0,49 & 0,48 & 7,46 & 7,79 & 0,52 & 0,51 \\
\hline 2001 & 10,85 & 10,90 & 0,48 & 0,47 & 1,86 & 1,93 & 0,43 & 0,43 & 6,20 & 6,24 & 0,49 & 0,48 & 7,27 & 7,42 & 0,50 & 0,49 \\
\hline 2002 & 12,30 & 12,43 & 0,55 & 0,54 & 2,16 & 2,29 & 0,49 & 0,50 & 7,03 & 7,17 & 0,56 & 0,56 & 8,49 & 8,65 & 0,59 & 0,57 \\
\hline 2003 & 14,69 & 14,81 & 0,65 & 0,64 & 2,55 & 2,74 & 0,58 & 0,60 & 8,53 & 8,45 & 0,67 & 0,66 & 10,23 & 10,19 & 0,71 & 0,67 \\
\hline 2004 & 17,38 & 17,80 & 0,77 & 0,77 & 3,20 & 3,38 & 0,73 & 0,74 & 9,92 & 10,05 & 0,78 & 0,78 & 12,93 & 12,70 & 0,90 & 0,84 \\
\hline 2005 & 19,69 & 20,41 & 0,88 & 0,89 & 3,49 & 3,60 & 0,80 & 0,79 & 11,35 & 11,82 & 0,90 & 0,92 & 14,04 & 14,17 & 0,97 & 0,94 \\
\hline 2006 & 22,01 & 22,42 & 0,98 & 0,97 & 3,92 & 4,15 & 0,90 & 0,91 & 12,46 & 12,57 & 0,99 & 0,98 & 15,84 & 15,64 & 1,10 & 1,03 \\
\hline 2007 & 26,70 & 27,65 & 1,19 & 1,20 & 5,40 & 5,49 & 1,24 & 1,21 & 14,71 & 15,20 & 1,16 & 1,18 & 17,65 & 18,86 & 1,22 & 1,24 \\
\hline 2008 & 34,24 & 35,58 & 1,52 & 1,55 & 7,38 & 7,38 & 1,69 & 1,62 & 19,22 & 20,21 & 1,52 & 1,57 & 22,03 & 24,01 & 1,53 & 1,58 \\
\hline 2009 & 25,29 & 26,31 & 1,13 & 1,14 & 5,39 & 5,50 & 1,23 & 1,21 & 14,53 & 15,08 & 1,15 & 1,17 & 15,17 & 16,12 & 1,05 & 1,06 \\
\hline 2010 & 27,72 & 28,67 & 1,23 & 1,25 & 5,49 & 5,82 & 1,25 & 1,28 & 15,24 & 15,59 & 1,21 & 1,21 & 16,21 & 17,06 & 1,12 & 1,13 \\
\hline 2011 & 36,40 & 36,92 & 1,62 & 1,61 & 7,21 & 7,80 & 1,65 & 1,72 & 19,81 & 19,71 & 1,57 & 1,53 & 20,33 & 22,61 & 1,41 & 1,49 \\
\hline 2012 & 34,08 & 34,46 & 1,52 & 1,50 & 7,04 & 7,11 & 1,61 & 1,57 & 19,15 & 19,31 & 1,52 & 1,50 & 19,82 & 21,82 & 1,37 & 1,44 \\
\hline
\end{tabular}

Nota: Unidade - US\$ bilhões; M - Importações; X - Exportações; (\%) - Índice - média 2000 a 2012 = 100; * Exceto tratores.

Fonte: Elaboração própria a partir dos dados do Comtrade. 
deixando claro que há intenso comércio entre as filiais das empresas nestes países envolvendo peças e máquinas. Os países da Ásia e das demais regiões têm participação relativamente pequena neste comércio internacional, sendo mais importante a produção interna.

Sartti, Sabbatini e Vian (2009) apontam que existem boas perspectivas para a demanda mundial por alimentos e que as regiões com potencial para a expansão da produção e da área são as dos países em desenvolvimento, especialmente a América Latina e África, como mostra a Tabela 3.

Pode-se entender esta predominância do comércio de implementos e peças pela estratégia de produção das empresas, que centralizam em algumas fábricas a produção de determinados tipos de equipamentos dedicados a certas culturas. A produção de peças segue a mesma lógica, sendo que há um grande fluxo entre as filiais das empresas no que tange a sensores, motores e equipamento eletrônico para máquinas usadas na agricultura de precisão.

Ao analisar o relatório da Freedonia, Sartti, Sabbatini e Vian (2009) ressaltam que os países desenvolvidos deverão manter sua tendência de crescimento por conta dos investimentos em biocombustíveis e da crescente tendência de uso de novas tecnologias, como a agricultura de precisão, o uso de satélite para transmissão de dados para controle das atividades e, também, para atividades de adubação e pulverização e integração entre máquinas e implementos. Isto demanda a renovação da frota, pois estes equipamentos não podem ser adaptados às máquinas antigas.

A indústria mundial de máquinas e equipamentos é um setor oligopolizado mundialmente. Três empresas podem ser destacadas como as mais importantes no mundo atualmente: $\mathrm{CNH}$ Case New Holland, Agco e John Deere. Elas atuam em todos os continentes através de fábricas próprias e, também, parcerias com empresas locais.

Na Tabela 4 avalia-se a concentração a partir das três grandes empresas globais. A tabela traz a estimativa da Freedonia para o mercado global em 2002, 2005, 2007 e 2011, e a participação aproximada com base no valor de vendas liquidas de cada empresa. Com a falta de dados para constituição da participação das empresas, neste trabalho avaliou-se a participação no mercado para as maiores. Percebe-se uma relativa estabilidade na liderança da Deere neste período, sendo que a $\mathrm{CNH}$ perdeu participação relativa e a AGCO cresceu $45,3 \%$, refletindo a estratégia de fusões e aquisições.

As empresas a seguir têm atuação local e/ou regional: Claas, da Alemanha, Kubota e Yanmar, do Japão e Mahindra, da Índia. As seguintes empresas têm atuação de caráter local: Bobard, da França,

Tabela 3. Área agriculturável por blocos de países - (milhões de ha)

\begin{tabular}{lccc}
\hline & $\mathbf{1 9 9 7 - 9 9}$ & $\mathbf{2 0 1 5}$ & 2030 \\
\hline Mundo & 1608 & nd & nd \\
Países em Desenvolvimento & 956 & 1017 & 1076 \\
Países industriais & 387 & nd & nd \\
Países em transição & 265 & nd & nd \\
\hline
\end{tabular}

Fonte: Sartti, Sabbatini e Vian (2009).

Tabela 4. Market share internacional em máquinas agrícolas automotrizes

\begin{tabular}{lcccc}
\hline & $\mathbf{2 0 0 1}$ & $\mathbf{2 0 0 5}$ & $\mathbf{2 0 0 7}$ & $\mathbf{2 0 1 1}$ \\
\hline DEERE & $21 \%$ & $15 \%$ & $13 \%$ & $19 \%$ \\
CNH & $17 \%$ & $17 \%$ & $16 \%$ & $11 \%$ \\
AGCO & $5 \%$ & $8 \%$ & $7 \%$ & $7 \%$ \\
Mercado mundial - US\$ bilhões & 53,50 & 70,20 & 93,20 & 125,50 \\
\hline
\end{tabular}

Fonte: Sartti, Sabbatini e Vian (2009), relatório anual das empresas e estimativa de mercado da Freedonia. 
Carraro, da Alemanha, Renault Agriculture, Argo, da Itália, entre outras. O Quadro 1 resume as empresas e seus locais de atuação.

Fonseca (1990) aponta a Deere como a líder de mercado nos anos 1980, com cerca de $20 \%$ do mercado mundial, seguida pela Case/ $\mathrm{IH}(15 \%)$, Massey (10\%) e Ford (5\%). Juntas, estas empresas respondiam por cerca de $50 \%$ do market share deste segmento. A John Deere consolidou sua liderança, mantendo um market share da ordem de $13 \%$, seguido pela Case, com 10,6\% e AGCO, com $6,9 \%$. Estes dados são diferentes da realidade nacional, em que a concentração é maior. No Brasil, as principais empresas que operam no setor atualmente são a AGCO, CNH Case New Holland, John Deere e Agrale, sendo que as duas primeiras são responsáveis por mais de $70 \%$ das vendas internas.

Em termos históricos, este setor passou por um importante processo de fusões e aquisições, destacando-se, nos anos 1980, a aquisição da International Harvester pela Case e da New Holland pela Ford. Nos anos 1990, houve a fusão destas duas empresas que formam a atual $\mathrm{CNH}$ Case New Holland e que faz parte do Grupo Fiat após processo de integração com a Fiat Allis.

O processo de fusões e aquisições foi importante para consolidar o setor, aproveitando sinergias entre as marcas e viabilizando a entrada em novos mercados sem a necessidade de construção de novas fábricas. Assim, não há elevação substancial da capacidade instalada, mas uma otimização na alocação das atividades produtivas.

O segmento de implementos agrícolas mostrou-se de difícil caracterização internacional por ser composto por pequenas e médias empresas em cada país. No Brasil, percebe-se que há uma tendência de avanço das empresas de tratores para este segmento, um processo de diversificação produtiva.

Além disto, há também a tendência de consolidação de parcerias entre empresas de tratores e implementos, destacando-se as para a pesquisa e desenvolvimento. Isto é importante também para a atuação em nichos de mercado, como os tratores para frutas e colheitadeiras específicas, em que a produção conjunta permite ganhos de escala e sinergias operacionais.

\section{Síntese da evolução da indústria}

Conforme o histórico apresentado, o setor de máquinas e equipamentos agrícolas teve mudanças circunstanciais, que marcaram sua trajetória tecnológica e mudaram a maneira de os produtores agrícolas realizarem o cultivo no mundo. A dependência destas máquinas e equipamentos é cada vez maior, já que o benefício principal da mecanização é o aumento da produtividade. A mecanização agrícola deixa de ser opção e torna-se regra para os países que desejam competir em âmbito global, pois é a forma que permite maior aproximação entre a dinâmica da oferta e da demanda por produtos agrícolas.

Outra característica importante do setor de máquinas e equipamentos agrícolas é a permanência das principais empresas no mercado. Mesmo com um intenso processo de fusões e aquisições, as grandes empresas do setor se mantêm. O processo de fusões e aquisições neste setor é caracterizado justamente pela incorporação de empresas menores ou de setores próximos. Este processo traz evidências de que as empresas conquistam ganhos ao incorporar seus concorrentes residuais, concentrando cada vez mais o mercado e expandindo seus negócios através das estratégias full-line e long-line. Além disso, o processo de concentração deste mercado resulta em um menor número de empresas atuando no mercado, mas não em um menor número de marcas. A título de ilustração, a empresa AGCO (Massey Ferguson) incorporou a Kone, fabricante de tratores da marca Valtra, em meados dos anos 2000; no entanto, tanto a marca Massey Ferguson quanto a Valtra permaneceram no mercado. Atualmente, a AGCO é responsável pelas marcas de tratores Massey Ferguson, Challenger, Fendt e Valtra. Ao manter as marcas no mercado, a empresa incorpora consumidores com diferentes preferências, o que representa a estratégia de concorrência por diferenciação de produto. 
Quadro 1. Caracterização da indústria mundial de máquinas e implementos agrícolas

\begin{tabular}{|l|l|c|l|l|}
\hline \multicolumn{1}{|c|}{ Empresa } & \multicolumn{1}{|c|}{ Origem } & $\begin{array}{c}\text { Área de } \\
\text { atuação }\end{array}$ & \multicolumn{1}{c|}{ Produtos } & Parcerias \\
\hline Deere \& Co & Americana & Global & Tratores, colheitadeiras e implementos & Tianjin Tractor - Tiantuo (China) \\
\hline CNH (FIAT) & Ítalo-Americana & Global & Tratores, colheitadeiras e implementos & \\
\hline AGCO & Americana & Global & Tratores e colheitadeiras & GIMA - transmissões \\
\hline Kubota & Japão & Regional & Tratores, colheitadeiras de pequeno porte & Land Pride - Implementos \\
\hline Claas & Alemanha & Regional & Tratores e colheitadeiras & \\
\hline Yanmar & Japão & Regional & Tratores e cultivadores motorizadfos & \\
\hline Same Deutz Farh & Alemanha & Regional & Tratores e colheitadeiras & \\
\hline Argo & Itália & Regional & Tratores e colheitadeiras & \\
\hline Mahindra & Índia & Regional & & \\
\hline Bucher Industries & Alemanha & Regional & & Agco- Trator - fruticultura e vinhedos \\
\hline Kverneland & Noruera & Regional & & \\
\hline Bobard & França & Regional & Pulverizadores motorizados & \\
\hline Carraro & Itália & Regional & Tratores & John Deere \\
\hline Renault & França & Regional & Tratores & \\
\hline Fóton & China & Regional & Tratores e colheitadeiras & \\
\hline Eichner & Índia & Regional & Tratores & \\
\hline
\end{tabular}

Fonte: Sartti, Sabbatini e Vian (2009).

Sarti, Sabbatini e Vian (2009) analisam os principais fatores críticos de competitividade da cadeia de máquinas e implementos no mundo. Apontam que o oligopólio mundial deste segmento passou por grandes modificações estruturais e competitivas nos últimos anos por conta de fusões e aquisições em âmbito internacional e da emergência de empresas regionais que têm fortes parcerias com as grandes, conforme se pode ver pelo Quadro 1.
Por sua vez, os dados de produção e demanda mostram que há uma concentração da produção na Europa e Estados Unidos e da demanda nos países da Ásia e América Latina.

No Quadro 2 seguem, cronologicamente, os principais marcos no desenvolvimento dos tratores desde sua criação, em 1858, até 1985. Já no Quadro 3 são apresentadas, de forma resumida, as principais mudanças históricas no setor de máquinas e implementos agrícolas, divididas

Quadro 2. Principais marcos na evolução dos tratores, 1858 - 1985

\begin{tabular}{|c|c|c|}
\hline Data & Modelo & Principais Mudanças \\
\hline 1858 & Primeiro trator & J. W. Fawkes puxou um arado de oito discos utilizando um sistema com motor a vapor (41 toneladas) \\
\hline 1892 & Froelich & Primeiro trator movido a gasolina \\
\hline 1905 & & Primeira Indústria de Tratores - Hart-Parr Company \\
\hline 1917 & Fordson & Linha de produção - Primeiro trator montado em série \\
\hline 1921 & Lanz Bulldog & Poderia ser operado tanto com gasolina quanto óleo vegetal \\
\hline Década de 1920 & Modelo “D” & Custo de produção menor que o modelo Fordson \\
\hline 1925 & Farmall & $\begin{array}{l}\text { Primeiro trator adaptável à uma série de operações agrícolas e mecanismo que facilitava a elevação dos } \\
\text { implementos do nível do solo. }\end{array}$ \\
\hline 1932 & - & Primeiro trator com pneus \\
\hline 1938 & $95 \%$ das marcas & Substituição de rodas de ferro pelas rodas pneumáticas de borrachas \\
\hline 1939 & Ferguson & Introdução de levante hidráulico de três pontos \\
\hline 1952 & Ferguson & Introdução de sistema de direção hidráulica \\
\hline $1948-1968$ & Setor em geral & Aumento da potência de $27 \mathrm{HP}$ para $79 \mathrm{HP}$ \\
\hline $1970-1978$ & Setor em Geral & Introdução de turbo-compressor e intercooler nos motores a diesel \\
\hline $1979-1985$ & Setor em geral & Tratores equipados com sensores e sistema de controle automático \\
\hline 1990-atual & Setor em geral & $\begin{array}{l}\text { Oferta de equipamentos mais potentes, novos pneus, eletrônica embarcada, equipamentos para sensoria- } \\
\text { mento remoto. }\end{array}$ \\
\hline
\end{tabular}

Fonte: Quadro elaborado pelos autores a partir da revisão bibliográfica. 
em três grandes fases: de 1892 a 1945 - do surgimento das primeiras engenhocas destinadas ao cultivo agrícola até o término da Segunda Guerra Mundial; de 1946 a 1990 - período pós-guerra até início da grande abertura comercial; e 1991 a 2009 - início das grandes conglomerações e maior concentração dos produtores de máquinas e equipamentos agrícolas.

Os dados da Tabela 5 mostram que há um esforço importante das empresas em direcionar investimentos para a área de pesquisa e desenvolvimento, em busca de inovações, procurando melhorar o desempenho das máquinas. Percebe-se grande preocupação da John Deere, que investe cerca de 800 milhões de dólares por ano em pesquisa e desenvolvimento de novos produtos. Analisando-se o número de patentes depositadas em números absolutos, percebe-se que empresas de menor porte, como CLAAS e Mahindra têm obtido sucesso em seus investimentos em P\&D.

Pelas características da agricultura, as máquinas precisam ser adaptadas para as condições de cada região do mundo. Assim, embora a pesquisa e desenvolvimento de produto tendam a ser feitas nas sedes das empresas, é crescente a atividade de engenharia para adaptação das máquinas às regiões em que serão realmente utilizadas. Assim, a localização e a capacitação das subsidiárias são fatores de competitividade cada vez mais importantes para as empresas, que passaram a investir em novas unidades nas regiões em que o avanço da agricultura é maior. Como exemplo, pode-se destacar a criação de fábricas da Deere no Brasil e na Ásia, a reativa- ção da fábrica de Sorocaba (São Paulo) da Case e os acordos de cooperação da AGCO na Ásia (SARTTI, SABBATINI e VIAN, 2009).

\section{Considerações finais e agenda de estudos}

Após a análise da evolução histórica do setor pode-se perceber que as inovações não só originaram o setor como promoveram seu desenvolvimento, já que estas, além de novos produtos, geraram vantagens decisivas de custos e qualidade, proporcionando, no longo prazo, a expansão da produção. As características do mercado de máquinas agrícolas inviabilizam pequenas firmas no setor, a não ser em casos específicos. Isto se dá devido aos grandes investimentos necessários em plantas fabris, P\&D, propaganda e promoção de vendas, redes de distribuição e assistência técnica. Ao mesmo tempo em que a concentração deste mercado gera maior eficiência produtiva para as empresas através das economias de escala e escopo, possibilita também maior grau de liberdade para as empresas na definição de seus preços. Dada a concorrência acirrada entre as grandes empresas através de inovações e melhorias em seus produtos, a principal estratégia adotada para garantir uma demanda menos elástica é a diferenciação de produtos através da manutenção das marcas de tratores, colheitadeiras e implementos nos processos de fusão e aquisição.

Quando apresentados os números de patentes depositadas de equipamentos agrícolas,

Tabela 5. Principais patentes depositadas, desde 1998, das principais empresas no mundo

\begin{tabular}{lcccc}
\hline & $\begin{array}{c}\text { Patentes depositadas } \\
\text { desde 1998 }\end{array}$ & Implementos agrícolas & Mecânica dos Tratores & Eletrônica embarcada \\
\hline AGCO & 27 & $34.62 \%$ & $53.85 \%$ & $11.54 \%$ \\
Claas & 67 & $28.79 \%$ & $57.58 \%$ & $13.64 \%$ \\
Deere Co. & 133 & $21.97 \%$ & $67.42 \%$ & $10.61 \%$ \\
Fóton & 8 & $85.71 \%$ & $14.29 \%$ & - \\
Mahindra & 12 & $27.27 \%$ & $72.73 \%$ & - \\
CNH & 42 & $36.59 \%$ & $58.54 \%$ & $4.88 \%$ \\
\hline
\end{tabular}

Fonte: Elaboração dos autores a partir de pesquisa nas bases internacionais de patentes. 


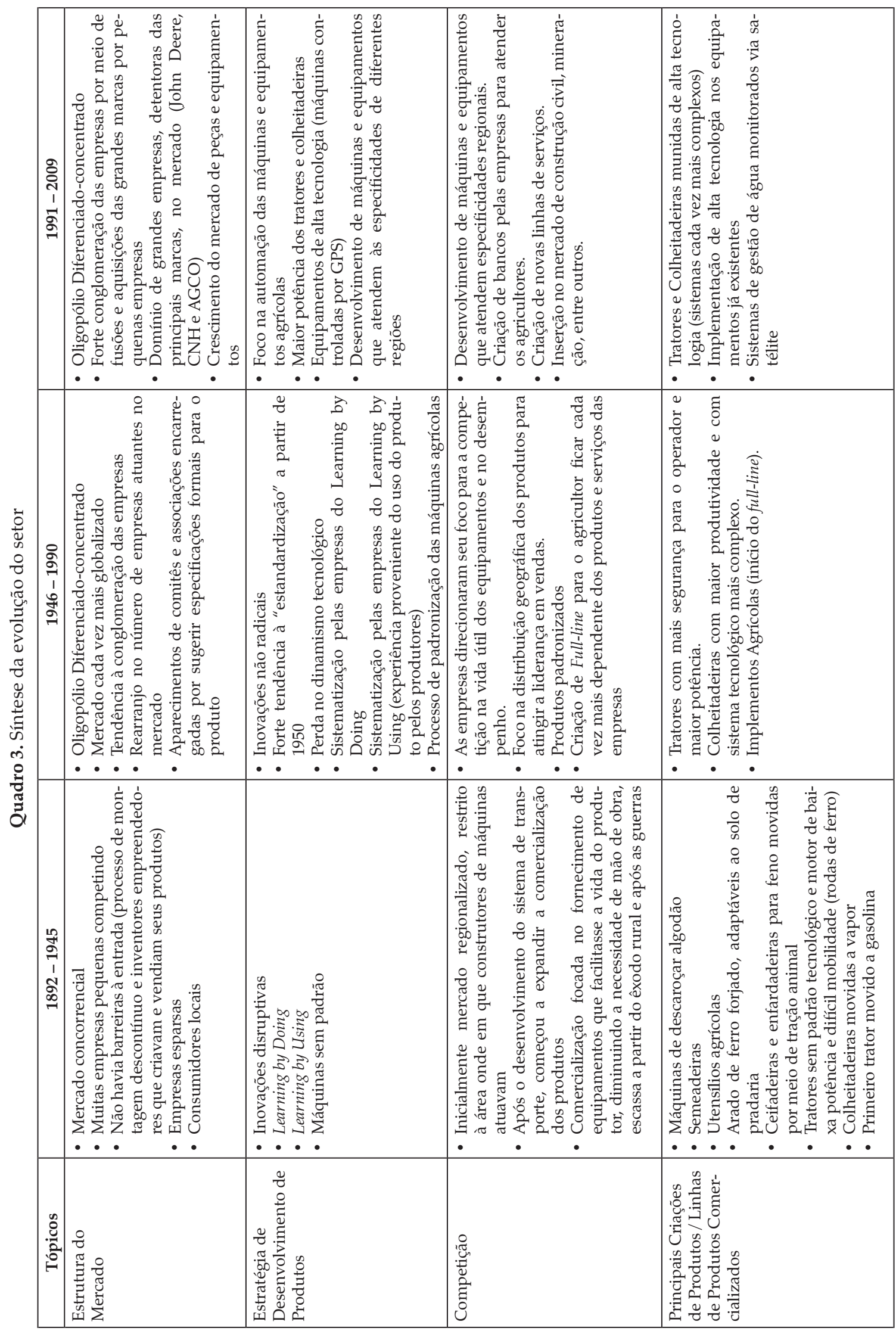




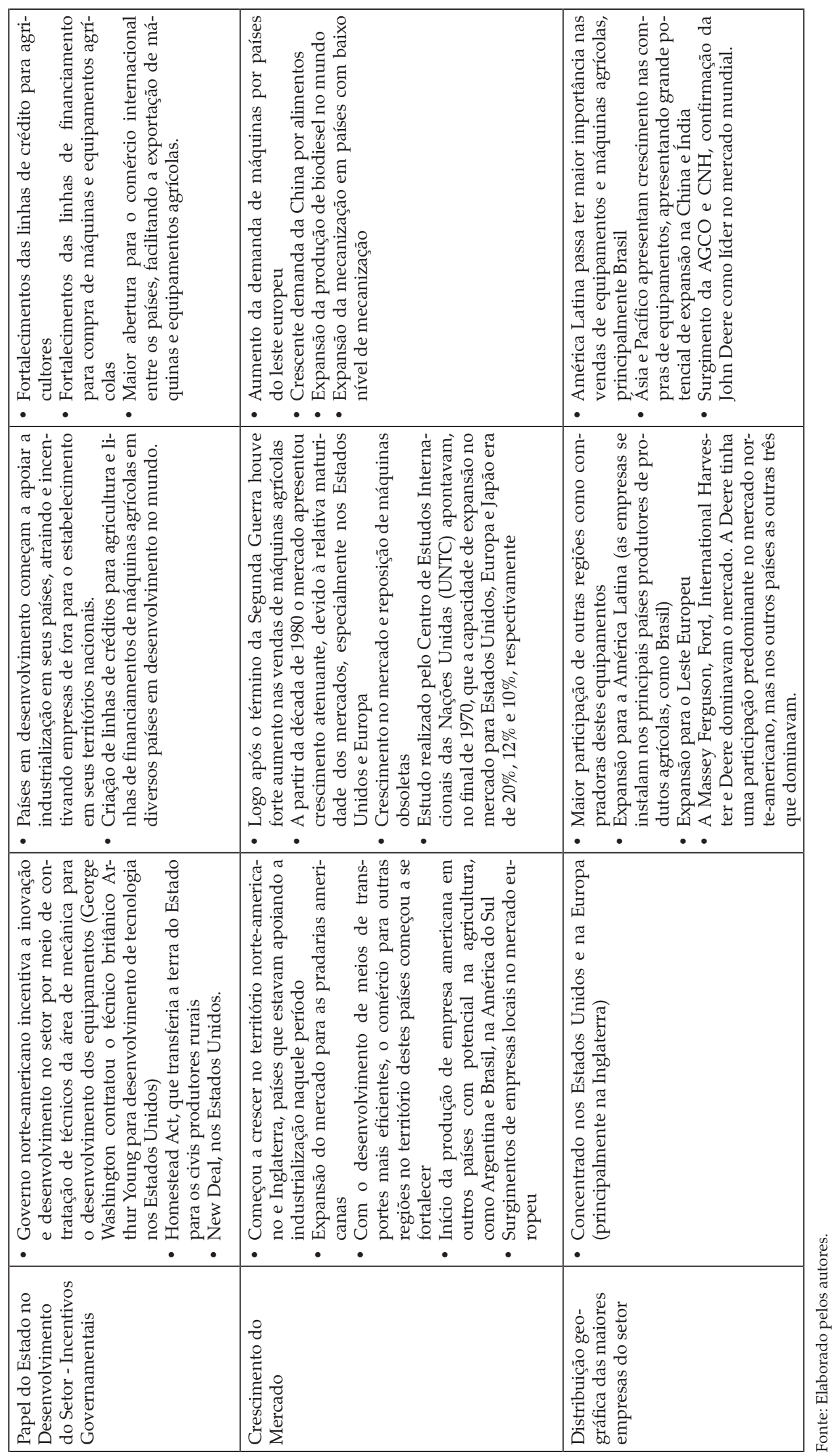


mecânica de tratores e eletrônica embarcada por empresas, sem grandes surpresas, nota-se que as empresas que investem mais em pesquisa e desenvolvimento têm número maior de patentes depositadas e são as que têm o maior percentual mundial de vendas.

Para a expansão dos mercados, as empresas têm instalado e ampliado suas plantas em diversos países. A distribuição geográfica passou a ser importante fator para o ganho de mercado. Mercados como América Latina e Ásia estão em ascensão e apresentam grande potencial de expansão no uso de máquinas, sendo, desta forma, os potenciais destinos destas empresas nos próximos anos.

A atual estrutura de mercado confirma que o setor tem características de um oligopólio diferenciado-concentrado, classificado conforme sua estrutura técnica - produtiva (tamanho e número de empresas no mercado, tecnologia utilizada e características dos produtos). A estrutura concentrada é dada pelas barreiras à entrada que o setor apresenta (economias de escala, necessidade de grandes investimentos e necessidade de ampla rede de distribuição e assistência técnica).

O forte processo de fusão e aquisição que ocorreu nas últimas décadas no setor colaborou para a atual concentração da participação das vendas no mercado mundial nas mãos das três principais empresas atuantes no mercado. O poder de mercado não se reflete em preços, mas sim na margem de lucro; desta forma, se a estratégia é a redução de custos via fusão e aquisição, as firmas também aumentarão suas margens e, consequentemente, seu poder de mercado, se não repassarem esta redução de custos para o consumidor.

A competição no mercado destas empresas ocorre por meio da diferenciação e inovação de produtos, através de elevados gastos com pesquisa e desenvolvimento para a criação de novos modelos e desenhos, redução de preços e aumento da qualidade, visando atender as diferentes faixas de consumidores por nível de renda e preferências.

Como agenda de estudos, destaca-se a necessidade de trabalhos voltados para o levantamento histórico de empresas de menor porte, porém, com importância no desenvolvimento regional do setor, além das que estão começando a se internacionalizar, como as empresas chinesas e algumas europeias. $\mathrm{O}$ desenvolvimento da indústria no Brasil também é um tema relevante, já que o País é apontado como um importante mercado para as empresas do setor, além de possuir grande potencial para elevação do índice de mecanização e de expansão de suas fronteiras agrícolas.

\section{Referências bibliográficas}

AGCO. Anual Report. 1999-2008.

BJORNSON, B. e KLIPFEL, J. Farm equipment industry performance: past and future. The International Food and Agribusiness Management Review, v. 3, n. 1, p. 71-84, 2000. ISSN 1096-7508. Disponível em: <http://www.sciencedirect.com/science/article/pii/ S1096750800000288>.

BRUE, S. L. História do pensamento econômico. 6a . São Paulo: Pioneira Thomson Learning, 2005. ISBN 8522104247.

CHANDLER, A. D. Strategy and structure: chapters in the history of the industrial enterprise. MIT press, 1990. ISBN 0262530090.

CNH. Anual Report. 2000-2008.

DEERE, J. Anual Report. 1999-2008.

DOSI, G. Sources, procedures, and microeconomic effects of innovation. Journal of economic literature, p. 1120-1171, 1988. ISSN 0022-0515.

DOSI, G.; TEECE, D. J.; WINTER, S. Toward a theory of corporate coherence: preliminary remarks. Technology and enterprise in a historical perspective, p. 185-211, 1992.

FERREIRA, M. J. B. A indústria brasileira de tratores agrícolas e colheitadeiras: as estratégias de suas empresas em desenvolvimento de vantagens competitivas. 1995. 120 (Mestrado em Economia). Instituto de Economia, Universidade Estadual de Campinas, Campinas.

FONSECA, M. D. G. D. Concorrência e progresso técnico na indústria de máquinas para agricultura: um estudo sobre trajetórias tecnológicas. 1990. 268 (Doutorado). Instituto de Economia, Universidade Estadual de Campinas (UNICAMP), Campinas, São Paulo.

KRAMER, H. M. Harvesters and high finance: formation of the International Harvester Company. 
Business History Review, v. 38, n. 03, p. 283-301, 1964. ISSN 2044-768X.

KUDRLE, R. T. Agricultural tractors a world industry study. Cambridge, Mass: Cambridge, Mass. Ballinger Pub. Co., 1975.

LEME, M. F. P. Concentração e internacionalização de capital na indústria brasileira de alimentos. Piracicaba: Esalq, 1999a.

. Concentração e internacionalização de capital na indústria brasileira de alimentos. 1999b. (Mestrado em Economia Aplicada). Departamento de Economia, Administração e Sociologia Rural, Escola Superior de Agricultura "Luiz de Queiroz" Universidade de São Paulo, Piracicaba.

PUDUP, M. B. From farm to factory: structuring and location of the US farm machinery industry. Economic Geography, p. 203-222, 1987. ISSN 0013-0095.

SARTI, F; SABBATINI, R.; VIAN, C. E. F. PROJETO PIB: Perspectivas do Investimento em Mecânica. Projeto PIB,
Campinas, n. 7, p. 160, 2009. Disponível em: <http:// www.eco.unicamp.br/neit/images/stories/arquivos/ie_ ufrj_sp07_mecanica.pdf $>$.

TEDLOW, R. S. Sete Homense os Impérios que Construíram. São Paulo. Editora Futura, 2002.

VIAN, C. E. D. F. Expansão e diversificação do complexo agroindustrial sucroalcooleiro no Centro-Sul do Brasil-1980/96. 1997. 237 (Mestrado em Engenharia de Produção). Departamento de Engenharia de Produção (DEP), Universidade Federal de São Carlos (UFSCAR), São Carlos.

- Inercia e mudança institucional: estrategias competitivas do complexo agroindustrial canavieiro no centro-sul do Brasil. 2002. (Tese de doutorado). Instituto de Economia, Universidade Estadual de Campinas (UNICAMP) Campinas.

YIN, R. K. Case Study Research: design and methods (Applied Social Research Methods). Londres: Sage Publicat, 2008. 
